\title{
Tortopus Needham \& Murphy and Tortopsis Molineri (Ephemeroptera, Polymitarcyidae) new species and new records from Brazil and Ecuador
}

\author{
Carlos Molineri ${ }^{1}$, Frederico F. Salles ${ }^{2} \&$ Rafael Boldrini ${ }^{3}$
}

${ }^{1}$ CONICET, Instituto de Biodiversidad Neotropical, Facultad de Ciencias Naturales e IML, Universidad Nacional de Tucumán, M. Lillo 205, San Miguel de Tucumán, 4000 Tucumán, Argentina. carlosmolineri@gmail.com

${ }^{2}$ Laboratório de Sistemática e Ecologia de Insetos, Departamento de Ciências Agrárias e Biológicas, Universidade Federal do Espírito Santo, 29933-415 São Mateus-ES, Brazil. ffsalles@gmail.com

${ }^{3}$ Divisão de Curso de Entomologia, Instituto Nacional de Pesquisas da Amazônia, 69060-001 Manaus-AM, Brazil. rafaelboldrini@yahoo.com.br

\begin{abstract}
Tortopus Needham \& Murphy and Tortopsis Molineri (Ephemeroptera, Polymitarcyidae) new species and new records from Brazil and Ecuador. Tortopus Needham \& Murphy, 1924 and Tortopsis Molineri, 2010 with six and 10 species, respectively, are sister genera distributed in the Neartic and Neotropical regions. In spite that most species are known from the tropics of South America, only one species of each of these groups have been recorded from Brazil. Here we present distributional data expanding greatly the range of these groups including three new country records for Brazil: Tortopus igaranus Needham \& Murphy, 1924, Tortopsis limoncocha Molineri, 2010 and Tortopsis spatula Molineri, 2010. We describe a distinct new species, Tortopus ipixuna sp. nov., from male imagos, that present a unique subrectangular pedestal. Additionally we redescribe the male imago of Tortopus harrisi Traver, 1950 (previously known only from the holotype), and we give the first records for Tortopsis canum Gonçalves, DaSilva \& Nessimian, 2011 from Espírito Santo and for Tortopsis spatula from Ecuador. Some variations in morphological structures of these species are also described, illustrated and discussed.
\end{abstract}

KEYWORDS. Burrowing mayfly; Campsurinae; distribution; Ephemeroidea.

RESUMO. Tortopus Needham \& Murphy e Tortopsis Molineri (Ephemeroptera, Polymitarcyidae) nova espécie e novos registros de Brasil e Ecuador. Tortopus Needham \& Murphy, 1924 e Tortopsis Molineri, 2010 com seis e 10 espécies, respectivamente, são gêneros irmãos distribuídos nas regiões Neártica e Neotropical. A despeito da maioria das espécies ser conhecida de áreas tropicais da América do Sul, apenas uma espécie de cada um dos gêneros foi registrada para o Brasil. No presente estudo apresentamos dados que expandem significativamente a distribuição desses grupos, incluindo três registros inéditos para o Brasil: Tortopus igaranus Needham \& Murphy, 1924, Tortopsis limoncocha Molineri, 2010 e Tortopsis spatula Molineri, 2010. Descrevemos uma nova espécie, Tortopus ipixuna sp. nov., a partir de imagos que apresentam um distinto pedestal subretangular. Adicionalmente redescrevemos a imago macho de Tortopus harrisi Traver 1950 (previamente conhecida apenas pelo holótipo), e registramos Tortopsis canum Gonçalves, Da-Silva \& Nessimian, 2011 pela primeira vez para o Espírito Santo, e Tortopsis spatula para o Equador. Algumas variações em estruturas dessas espécies também são descritas, ilustradas e discutidas.

PALAVRAS-CHAVE. Efemerópteros escavadores; Campsurinae; distribuição; Ephemeroidea.

The subfamily Campsurinae (Ephemeroptera: Polymitarcyidae) is represented by three genera distributed in the Neartic and Neotropical regions: Campsurus Eaton 1868, Tortopus Needham \& Murphy 1924 and Tortopsis Molineri 2010, reaching 61 known species (Dominguez et al. 2006; Molineri 2010; Emmerich \& Molineri 2011; Gonçalves et al. 2011). Tortopus and Tortopsis are considered sister genera in the phylogenetic analysis proposed by Molineri (2010). The biology of this group is poorly known. Nymphs of Tortopsis inhabit U-shaped tunnels burrowed in river clay banks, and adults of both genera are attracted to light traps in the vicinity of such habitats (Molineri 2010).

The genus Tortopus, with six described species (Molineri 2010), is known in Brazil only by T. harrisi Traver, 1950, from Mato Grosso and Mato Grosso do Sul states (Traver 1950; Molineri et al. 2010), and the male imago is only known from the holotype (Traver 1950). The genus Tortopsis, with 10 described species, was recently recorded from Brazil, from Rio de Janeiro state, with the description of the imagos of T. canum Gonçalves, Da-Silva \& Nessimian, 2011 (Gonçalves et al. 2011).

We give here some drawings and comparative notes for the newly collected male imagos of Tortopus harrisi, the first Brazilian records for T. igaranus Needham \& Murphy, 1924, previously known from Peru and Colombia, we describe a new species of the genus from Amazonas state, Brazil, and record two additional species of the genus Tortopsis from Brazil: Tortopsis limoncocha Molineri, 2010 and Tortopsis spatula Molineri, 2010. Additionally we also record the last species from Ecuador. The key to male imagos of Tortopus from Molineri (2010) is amended to include the new species. A map including all the geographic records of the South American species is presented.

\section{MATERIAL AND METHODS}

The specimens are preserved in ethanol; some parts were mounted on slides using Euparal or Canada Balsam as mount- 
ing media except for wings that were mounted dry. The key and terminology proposed by Molineri (2010) was used to identify the species and to describe morphological structures, respectively. The map was edited with the free software DIVAGIS (www.diva-gis.org, version 7.1.7.2), including all known geographical records for the South American species of Tortopus and Tortopsis in decimal format. The material is housed in the following institutions: CZNC (Coleção Zoológica Norte Capixaba, São Mateus, Espírito Santo), INPA (Instituto Nacional de Pesquisas da Amazônia, Manaus) and IBN (Instituto de Biodiversidad Neotropical, Tucumán, Argentina).

\section{RESULTS}

\section{Tortopus ipixuna sp. nov.}

Type material. Holotype male imago (INPA) from Brazil, Amazonas State, Ipixuna, comunidade Estirão da Preta, Rio Liberdade, light trap, 07²1'46”S / 7152'07'W, 11.v.2011, A. Somavilla col.

Additional material. 1 male imago (CZNC) with posterior half of abdomen broken off and lost, same data as holotype.

Male imago. Length (mm): body, 10.7; forewing, 10.2; hind wing, 4.7; foreleg, 4.5 (cerci broken off and lost). General coloration yellowish. Head yellowish shaded strongly with gray on a band between lateral ocelli, shaded more diffusely with gray on occiput; head not shaded posterior to median ocellus and along medial line. Antennae: scape and pedicel completely shaded with gray except, flagellum hyaline. Thorax. Pronotum translucent shaded gray along hind margin of anterior ring, shaded more strongly on large subquadrate area on posterior ring, except for pale medial line and sublateral posterior oblique dash; propleura and prosternum translucent yellow, shaded slightly with gray. Mesonotum orangish yellow, shaded with gray along parapsidal sutures forming a pair of bands that become darker and converge posteriorly on mesoscutellum; mesopleura and mesosternum slightly paler, not shaded; furcasternal protuberances diverging posteriorly from anterior margin. Metanotum orangish yellow shaded gray medially; metapleura and sternum not shaded. Legs. Forelegs yellowish white shaded completely with gray except on trochanter and claws, shading stronger on tibia and tarsus, apex of tarsus with three small lobes (al in Fig. 4); middle and hind legs yellowish. Wings. Forewing with hyaline membrane except shaded gray basally on C, Sc and anal areas, and whitish stigmatic area; all veins shaded gray. Hind wing similar in coloration to forewing, except membrane shaded completely with gray, shading getting paler apically. Abdomen whitish yellow shaded with gray dorsally, except on intersegmental membranes and pale lateral dashes on terga I-VII; a very thin medial black line present on terga IV-IX; tergum IX with a submedian elongated curved and pale dash; tergum $\mathrm{X}$ with a pair of transversal blackish dashes near posterolateral angle. Abdominal sterna translucent yellowish white, not shaded, gill sclerites yellowish. Genitalia (Figs. 5-7): sternum IX shaded very slightly with gray, darker submedially near fore margin; pedestals whitish subrectangular without a well-developed parastylus, only a small pointed apex on this corner (Fig. 7); forceps whitish shaded gray along outer margin; penes whitish translucent except outer apical margin yellowish, apex as in Fig. 6. Short terminal filament whitish translucent shaded gray, cercus broken off and lost except for yellowish basal segment shaded gray.

Female imago and nymph. Unknown.

Etymology. From the type locality Ipixuna, which in tupi means "black water" (Ferreira 1986), name given by the inhabitants to the main river of the region.

Diagnosis. Tortopus ipixuna sp. nov. can be separated from all other species of the genus by the following combination of characters: 1) male forewing length $10.2 \mathrm{~mm}$, membrane hyaline; 2) pedestal subrectangular (Fig. 7) with parastylus barely discernible, only expressed as an acute point in the posterolateral angle of pedestal (ps in Fig. 7), basal extension of pedestal poorly developed (be in Fig. 7); 3) ventral knob relatively small (Fig. 7); 4) penes relatively thin at base (fused portion), not strongly expanded distally (Figs. 5-6); and 5) a relatively pale species, gray shading on occiput except pale medial line.

The key for male imagos of Tortopus in Molineri (2010) may be modified by adding an initial couplet as follows:

Pedestal longer than wide, with small basal extension (be in Fig. 7); parastylus reduced, expressed only as an acute point (ps in Fig. 7) Tortopus ipixuna Pedestal wider than long (not including the parastylus), with a well developed basal extension (be in Fig. 2), parastylus at least $1 / 2$ the length of pedestal (ps in Fig. 2) to couplet 1 in Molineri (2010)

\section{Tortopus harrisi Traver}

Tortopus harrisi Traver 1950: 604; Domínguez 1985: 69; Domínguez et al. 2006: 585; Molineri et al. 2010: 65; Molineri 2010: 20.

Material. Seven male imagos ( 3 in INPA, 2 in CZNC, 2 in IBN) from Brazil, Amazonas State, Ipixuna, comunidade Estirão da Preta, Rio Liberdade, light trap, 07²1'46"S / 71'52'07'W, 13.v.2011, A. Somavilla col.; and 1 male imago (CZNC) from Brazil, Parana State, Rio Paraná, Lagoa dos Patos, 22 $43^{\circ}$ '12'S / 5317'37'W, 26.xi.1997, A. Takeda leg.; and 1 male and 5 female imagos (CZNC) same data except date, 22.iv.1998; and 2 male imagos (CZNC) from Brazil, Espírito Santo State, Nova Venécia, Rio São Mateus, light trap, 18³9'51.4”S / 40³0'44.9”W, 16.iv.2012, K. B. Angeli col.

Male imago. Length (mm): body, 10.7; forewing, 10.2; hind wing, 4.7; foreleg, 4.5 (cerci broken off and lost). General coloration yellowish shaded with purplish gray. Color pattern on body similar to Tortopus ipixuna except: mesonotum widely shaded with purplish gray along parapsidal suture and its sides, and on an anteromedian mark on mesoscutum. Legs whitish, foreleg shaded strongly with gray only on tarsus. Wings. Membrane of fore and hind wing hyaline completely but slightly tinged with purplish gray, veins same color but darker. Abdomen whitish extensively 

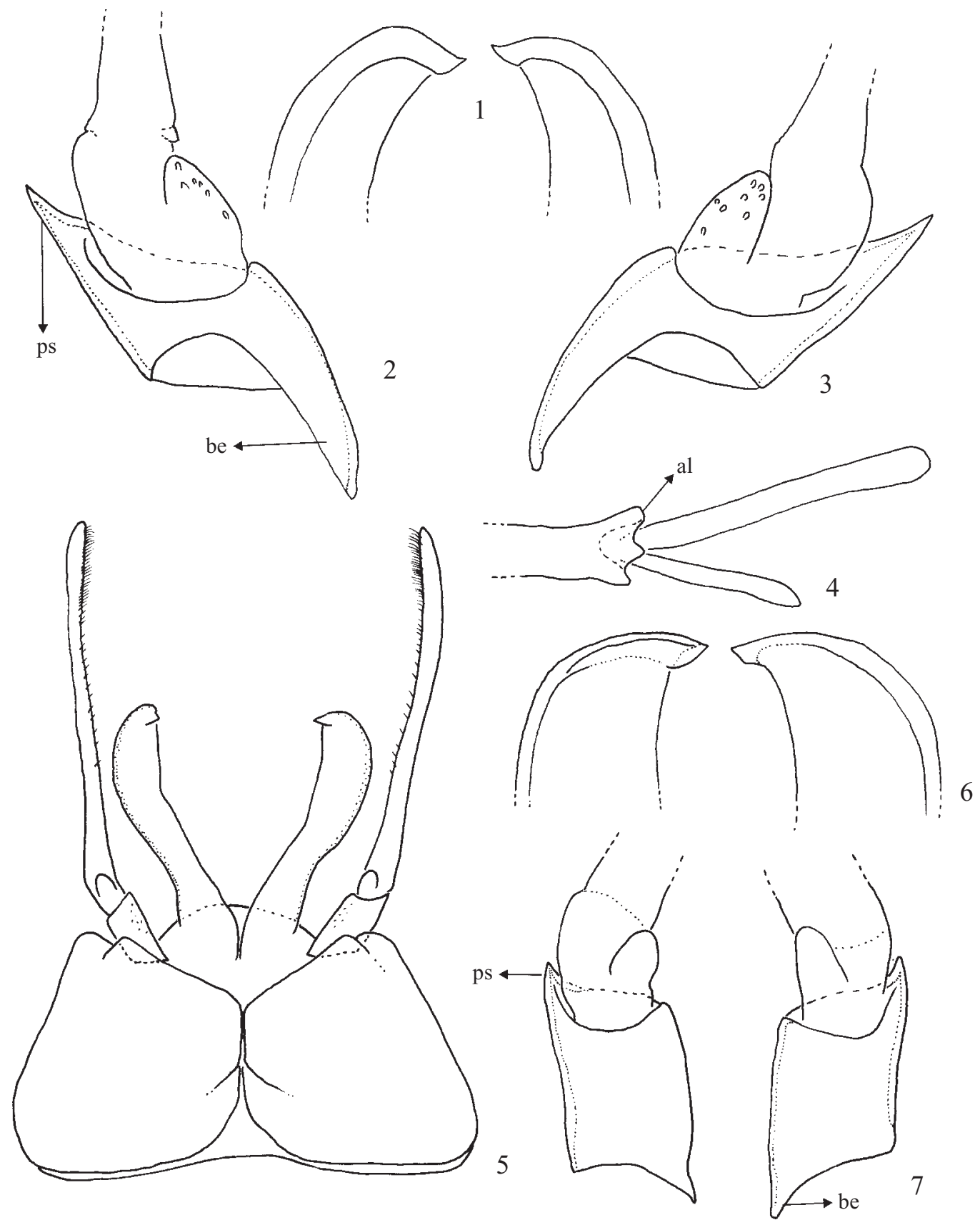

Figs. 1-7. Male genitalia, ventral view. Figs 1-3, Tortopus harrisi: 1, detail of apex of penes; 2-3, pedestals and base of forceps. Figs. 4-7, Tortopus ipixuna: 4, fore tarsal claw; 5, genitalia; 6 , detail of apex of penes; 7, pedestals. Abbreviations: al $=$ apical lobes of fore tarsus; be $=$ basal extension of pedestal; ps = parastylus.

shaded with purplish gray, very thin gray medial line on all terga; sterna whitish not shaded. Genitalia (Figs. 1-3): whitish except apex of parastylus and sclerotized margin of penes yellowish; acutely pointed parastylus (Figs. 2-3), 0.5 the length of pedestal (not including the basal extension in the measure); penes in some males are curved and directed ventrally (in the position of copula), apex acutely extended as in Fig. 1. Short terminal filament whitish translucent shaded gray, cercus completely and strongly shaded with purplish gray on basal $2 / 3$, except a joins and $t$ distal $1 / 3$, whitish.
Diagnosis. Tortopus harrisi was known until now from the male holotype and some female adults and nymphs attributed to this species (Traver 1950; Molineri et al. 2010; Molineri 2010). Additional information from the males reported here helped to improve its diagnosis: 1) male forewing length $9.2-10.5 \mathrm{~mm}$, female forewing $10.5-15.0 \mathrm{~mm}$, wing membrane slightly smoky in some populations; 2) parastyli pointed, very short, around 0.5 the length of pedestal (Figs. 2-3);3) ventral knob relatively large; and 4) penes relatively narrow basally, not expanded, sclerotized margin 


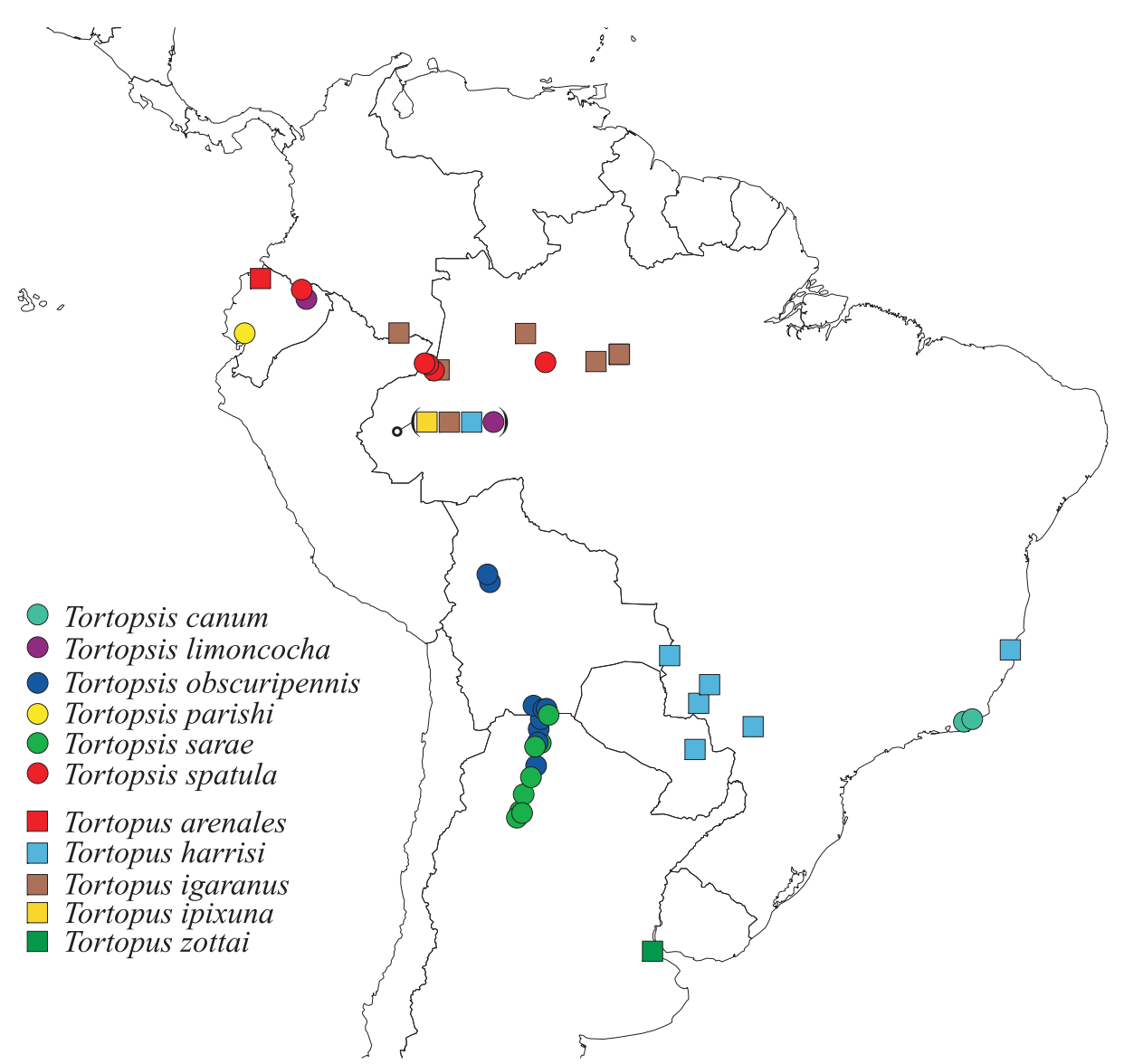

Fig. 8. Distribution of South American species of Tortopus and Tortopsis. All records from Brazil are newly reported here (except for T. canum in RJ and two records of $T$. harrisi).

ending as in Fig. 1, almost all the males show the penes curved and directed ventrally.

\section{Tortopus igaranus Needham \& Murphy}

Tortopus igaranus Needham \& Murphy 1924; Ulmer 1942: 111; Traver 1950: 600; Domínguez 1985: 69; Domínguez et al. 2006: 585; Molineri 2010: 11 .

Material. One male and 2 female imagos (INPA) from Brazil, Amazonas State, Ipixuna, comunidade Estirão da Preta, Rio Liberdade, light trap, 07²1'46”S / 71'52'07'W, 13.v.2011, A. Somavilla col.; 9 male and 4 female imagos (CZNC) from Brazil, Amazonas State, Ilha da Paciência, Nossa Senhora da Conceição, Lago Jacitara, 3¹6’40.7”S / 60¹6’34.5”W, 19.ix.2003, light trap; 3 male imagos (CZNC) from Brazil, Amazonas state, Anamã, Boa Esperança, Paraná-Barco, 3³9”25.8S / 61³0’08.2”W, 17.ix.2003, light trap; and 2 male imagos (CZNC) from Brazil, Amazonas state, Rio Japurá, 14.iii.1980, A. Storti F.

Notes. Body coloration much paler than the other two species treated here, light yellowish white, purplish gray shading on dorsum very slightly marked. The whitish fore leg is shaded gray completely except trochanter and claws, femur paler than tibia-tarsus. Wings membrane hyaline, slightly tinged with purplish gray basally on $\mathrm{C}$, Sc and anal areas, veins light purplish gray, turning hyaline toward apex. Geni- talia with parastylus relatively long, slender and very acute. In lateral view the parastylus reach 0.27 of the length of forceps from base; in ventral view the parastylus is 2.5 times the length of pedestal (the measure does not include the basal projection that is hidden below the IX sternum). One of the males from Rio Japurá presents parastylus relatively short in comparison (1.5 the length of pedestal).

Diagnosis. With the new morphological data gathered here, the two first characters in the diagnosis of T. igaranus (from Molineri 2010) are modified as follows: 1) forewing length 8.0-9.5 mm (female 8.5-12.5 mm), membrane hyaline; 2) parastyli relatively long (1.5-2.5 times length of pedestal) and thin from its base.

\section{Tortopsis canum Gonçalves, Da-Silva \& Nessimian}

Tortopsis canum Gonçalves et al., 2011: 51.

Material. Two male and 2 female imagos (CZNC) from Brazil, Espírito Santo State, São Mateus, Sítio Santa Maria, Rio São Mateus, light trap, 18³9'17’S / 3959’36”W, 13-14.vi.2012, Pensilvania trap, K. B. Angeli col.

Notes. This species was only known from the type locality in Rio de Janeiro, we are firstly recording it for Espírito Santo. 


\section{Tortopsis limoncocha Molineri}

Tortopsis limoncocha Molineri 2010: 30; Gonçalves et al. 2011: 54.

Material. One male and 1 female imagos (INPA) from Brazil, Amazonas state, Ipixuna, comunidade Santa Catarina, light trap, 10.v.2011, A. Somavilla col.; 2 male and 6 female imagos (CZNC) from Brazil, Amazonas State, Ipixuna, comunidade Estirão da Preta, Rio Liberdade, light trap, 07²1'46"S / 71 '52'07'W, 13.v.2011, A. Somavilla col.; and 2 female adults (INPA) same data except date: 11.v.2011.

Notes. Male imagos from Ipixuna (Brazil) reach a forewing length of $9.5 \mathrm{~mm}$ (those from the type locality in Ecuador, $11.0-11.8 \mathrm{~mm}$ ). The females of both localities are similar in size but females from Ipixuna present the wings membrane slightly tinted with yellowish.

\section{Tortopsis spatula Molineri}

Tortopsis spatula Molineri 2010: 33; Gonçalves et al. 2011: 54.

Material. One female (CZNC) from Brazil, Amazonas State, Tefé, São João do Catuaí, Igarapé Jutaí, Igarape, 341'52.8”S/ 6409'18”W, 12.ix.2003, light trap; 1 male and 3 female imagos (IBN) from Ecuador, Napo, Lago Agrio, (1 km S), 22.viii.1975, blacklight, Andrea Langley.

Notes. This species is easily identified because the female shows V-shaped sockets and the eggs present a long thread coiled around (Molineri 2010). The specimens from Ecuador are not pale as those of the type series, they have bodies strongly shaded with black.

\section{DISCUSSION}

Previously only two records of Tortopus harrisi from Mato Grosso (reported in the original description by Traver 1950) and Mato Grosso do Sul (Molineri et al. 2010), and one of Tortopsis canum in Rio de Janeiro (Gonçalves et al. 2011) were known from Brazil. With the new information given here, two additional species for each genus are reported for this country: Tortopus igaranus, Tortopus ipixuna, Tortopsis limoncocha and Tortopsis spatula. The distribution of Tortopus harrisi is greatly expanded, including records in Amazonas, Espírito Santo and Paraná states. Also the known range of Tortopsis spatula is incremented considerably to the east (Amazonas state, Brazil) and the west (Napo province, Ecuador) of its previous record in Colombia.

Tortopus ipixuna shows unique characters in pedestals: the subrectangular shape (longer than wide), the reduced parastylus and the poorly developed basal extension. An additional putative apomorphy to the clade formed by Tortopus and Tortopsis (Molineri 2010) is proposed, since all the species studied here present three apical lobes in fore tarsus of males (al in Fig. 4), characteristics not found in other genera of the family (Campsurus Eaton 1868, Asthenopus Eaton 1861).

\section{ACKNOWLEDGMENTS}

For loan of material from Ipixuna, we thank to Programa de Apoio a Núcleos de Excelência (Pronex) of the Fundação de Amparo à Pesquisa do Estado do Amazonas (FAPEAM, Edital 016/2006, Proc. 1437/2007). CM thanks National Council of Scientific Research of Argentina (CONICET) for External Fellow to Espírito Santo and for financial support (PIP 1484). We also thank the National Council of Technological and Scientific Development of Brazil (CNPq) for financial support to the project "PELD - Bacia do Rio São Mateus", process number 558246/2009-5.

\section{REFERENCES}

Domínguez, E. 1985. El género Tortopus Needham y Murphy (Ephemeroptera: Polymitarcyidae) en la Argentina. Physis B 43: 69-72.

Domínguez, E.; C. Molineri; M. L. Pescador; M. D. Hubbard \& C. Nieto. 2006. Ephemeroptera of South America, p. 1-646. In: J. Adis, J. R. Arias, G. Rueda-Delgado \& K. M. Wantzen (eds.). Aquatic Biodiversity of Latin America. Vol. 2, Moscow-sofia, Pensoft, 646 p.

Emmerich, D. \& C. Molineri. 2011. A new species of Campsurus (Ephemeroptera: Polymitarcyidae: Campsurinae) from Argentina and Uruguay and redescription of $C$. evanidus and $C$. jorgenseni with new synonymies. Zootaxa 2965: 51-60.

Ferreira, A. B. H. 1986. Novo Dicionário da Língua Portuguesa. Segunda edição. Rio de Janeiro, Nova Fronteira.

Gonçalves, I. C.; E. R. Da-Silva \& J. L. Nessimian. 2011. First record and new species of Tortopsis Molineri, 2010 (Ephemeroptera, Polymitarcyidae) from Brazil. Zootaxa 2866: 50-54.

Molineri, C. 2010. A cladistic revision of Tortopus Needham \& Murphy with description of the new genus Tortopsis (Ephemeroptera: Polymitarcyidae). Zootaxa 2481: 1-36.

Molineri, C.; A. Siegloch \& K.O. Righi-Cavallaro. 2010. The nymph of Tortopus harrisi Traver (Ephemeroptera: Polymitarcyidae). Zootaxa 2436: 65-68.

Needham, J. G. \& H. E. Murphy. 1924. Neotropical mayflies. Bulletin of the Lloyd Library of Botany, Pharmacy and Materia Medica, Entomological series 24: 1-79.

Traver, J. R. 1950. Notes on Neotropical mayflies. Part. IV. Family Ephemeridae (continued). Revista de Entomologia 21: 593-614.

Ulmer, G. 1942. Alte und neue Eintagsfliegen (Ephemeropteren) aus Südund Mittelamerika. Stettiner Entomologische Zeitung 103: 98-128. 